\title{
Salt intakes in sub-Saharan Africa: a systematic review and meta-regression
}

\author{
Oyinlola Oyebode ${ }^{1 *}$, Samuel Oti ${ }^{2,3}$, Yen-Fu Chen ${ }^{1}$ and Richard J. Lilford ${ }^{1}$
}

\begin{abstract}
Background: High sodium intake increases the risk of hypertension and cardiovascular diseases. For this reason the World Health Organization recommends a maximum intake of $2 \mathrm{~g}$ per day and a $30 \%$ reduction in population sodium intake by 2025. However, in global reviews, data on sodium intake in sub-Saharan Africa have been limited.

Methods: A systematic review was conducted to identify studies reporting sodium intake in sub-Saharan African populations. Meta-regression analyses were used to test the effect of year of data collection and method of data collection (urinary/dietary), as well as any association between sex, urban/rural status or a country's economic development, and population sodium intake.

Results: We identified 42 papers reporting 67 estimates of adult population sodium intakes and 12 estimates of child population sodium intakes since 1967. Of the 67 adult populations, 54 (81\%) consumed more than $2 \mathrm{~g}$ sodium/day, as did four of the 12 (33\%) child populations. Sixty-five adult estimates were included in the metaregression, which found that urban populations consumed higher amounts of salt than rural populations and that urine collection gave lower estimates of sodium intake than dietary data.

Conclusions: Sodium intake in much of sub-Saharan Africa is above the World Health Organization's recommended maximum intake and may be set to increase as the continent undergoes considerable urbanization. Few identified studies used stringent measurement criteria or representative population samples. High quality studies will be required to identify where and with whom to intervene, in order to meet the World Health Organization's target of a $30 \%$ reduction in population sodium intake and to demonstrate progress towards this target.
\end{abstract}

Keywords: Sodium chloride, Dietary, Sodium, Africa, Systematic review

\section{Background}

Non-communicable diseases (NCDs) are the leading cause of global disease burden $[1,2]$, with $80 \%$ of NCD mortality occurring in low- and middle-income countries (LMICs) [3]. Of these, the cardiovascular diseases (CVD), ischemic heart disease and stroke, are the leading causes of death and disability, and are increasing in prevalence $[1,2]$. Whereas ischemic heart disease predominates in high-income countries, stroke is the most important CVD in African countries [4]. In 2005, $87 \%$ of stroke death occurred in LMICs, rising to $94 \%$ of stroke deaths in people under 70 years old [5].

\footnotetext{
* Correspondence: o.r.o.oyebode@warwick.ac.uk

${ }^{1}$ Warwick Medical School, University of Warwick, Gibbet Hill Campus,

Coventry CV4 7AL, UK

Full list of author information is available at the end of the article
}

Excess sodium intake raises blood pressure, leading to hypertension, the principal preventable risk factor for stroke [6, 7]. Excess sodium is also a major risk factor for other CVDs and for stomach cancer [6-8]. It is possible that populations in sub-Saharan Africa are more vulnerable to the effects of a high sodium diet than other populations due to the greater prevalence of inter-uterine growth restriction, as well as genetic factors $[9,10]$.

The normal (physiological) requirement for sodium is likely to be between 0.1 and $1.0 \mathrm{~g}$ ( $2.5 \mathrm{~g}$ salt) daily [11]. Recommended intake is less than $2.0 \mathrm{~g}$ sodium $(5.0 \mathrm{~g}$ salt) for adults aged 16 and over, and this recommended maximum level of intake should be adjusted downwards in children ages 2-15 based on the energy requirements of children relative to those of adults [12]. The World 
Health Organization (WHO) Global Action Plan for the Prevention and Control of Non-Communicable Diseases 2013-2020 identifies nine key targets for the reduction of chronic disease, including "a $30 \%$ relative reduction in mean population intake of salt/sodium" [13]. The reason for a focus on a relative reduction rather than aiming to reduce salt intake to recommended levels reflects the observation that most populations have a mean sodium intake that considerably exceeds the $2.0 \mathrm{~g}$ recommendation [14, 15].

Given the WHO target, it is important to quantify current population salt intakes. This is particularly important in sub-Saharan Africa where the epidemiological transition is likely to result in dietary changes and a large increase in the prevalence of NCDs. In addition, resources for treatment of salt-associated diseases may not meet population needs so preventative strategies, such as salt reduction strategies, are key to averting the associated morbidity and mortality. To identify populations in which sodium intake is high, and to assess progress against the WHO sodium target, knowledge of sodium intake in sub-Saharan Africa is required.

Systematic reviews examining population salt intake globally have recently been conducted, however, the statistics reported for sub-Saharan African countries were limited $[15,16]$. We re-examined this question focusing on sub-Saharan Africa only, in order to maximize the data gathered.

\section{Methods}

\section{Search strategy}

MEDLINE and Google Scholar were searched on March 2, 2015 using comprehensive search terms [Table 1]. No language limits were applied. While no date limits were applied in the MEDLINE search, the Google Scholar search was restricted to articles published from 1960 onwards. Reference lists of included studies were also searched to identify further studies.

\section{Inclusion criteria}

In order to be considered for inclusion, identified studies must have reported salt or sodium intake based on $24 \mathrm{~h}$ or timed urinary collection, or on dietary analysis. Studies reporting spot or overnight urine collection were not eligible for inclusion. Studies were required to include a general population sample or a normotensive population sample from sub-Saharan Africa.

\section{Data extraction and handling}

Papers relating to the same study were examined together. Data was extracted independently by two researchers. This was done using a spreadsheet with the following headings:
Table 1 Search strategy

\begin{tabular}{l} 
Medline: \\
\hline 1. Exp Sodium Chloride, Dietary/ or exp Sodium, Dietary/ \\
2. Salt or sodium \\
3. Exp Africa/ \\
4.1 OR 2 \\
5. 3 AND 4 \\
6. Limit to humans \\
Google Scholar: \\
Note: Words in brackets are combined with an "OR" \\
(Africa Angola Benin Botswana "Burkina Faso" Burundi Cameroon "Cape \\
Verde" "Central African Republic" Chad Comoros Congo "Cote d'Ivoire" \\
Djibouti "Equatorial Guinea" Eritrea Ethiopia Gabon Gambia Ghana \\
Guinea Guinea-Bissau Kenya Lesotho Liberia Madagascar Malawi Mali \\
Mauritania Mauritius Mozambique Namibia Niger Nigeria Reunion \\
Rwanda "Sao Tome and Principe" Senegal Seychelles "Sierra Leone" \\
Somalia "South Africa" Sudan Swaziland Tanzania Togo Uganda "Western \\
Sahara" Zambia Zimbabwe) AND (salt sodium) AND (dietary diet intake \\
urine urinary) \\
\hline
\end{tabular}

1. Authors.

2. Year of publication.

3. Year of data collection.

4. Country of study.

5. Details of the sample.

6. Measurement used.

7. Quality assessment: Reliability and accuracy of measurement (after Powles and colleagues, 2013 [15]).

a. For urine collection (from high quality to low): $U 1-24 \mathrm{~h}$ urine with PABA validation; $U 2-24 \mathrm{~h}$ urine with exclusions based on observed/expected creatinine ratio or total urinary creatinine; $U 3-24 \mathrm{~h}$ urine with other strict urine collection protocol without use of PABA or creatinine; $U 4-24 \mathrm{~h}$ urine with other collection protocol or not recorded; U5 - Less than $24 \mathrm{~h}$ urine, but timed in order to correct to $24 \mathrm{~h}$

b. For dietary methods: D1 - Multiple short-term diet recalls; D2 - Food Frequency Questionnaire; D3 - Single dietary recall; D4 - Other (stated).

8. Quality assessment - Representativeness of sample population: $A$ - random sampling from explicitly stated sampling frame; $B$ - other sampling strategy.

9. Sample size.

10. Sodium intake (g/day). We extracted data for adults and children, male and female, for urban and rural groups, and for black and non-black ethnicity separately, when these were reported. Where necessary we used the conversion of $1 \mathrm{~g}$ sodium $=43.5 \mathrm{mmol}$ sodium, and $1 \mathrm{~g}$ sodium $=2.5 \mathrm{~g}$ salt. Where both 
dietary and urinary figures were available we extracted the urinary figures only.

11. Standard deviation of the mean sodium intake.

12. Standard error of the mean sodium intake.

Where there was any discrepancy arising in the data extraction it was resolved by the two reviewers (OO and $\mathrm{SO}$ ).
In cases in which data were not reported in published papers, corresponding authors were contacted to supply these results.

\section{Statistical analysis}

Random-effects meta-regression was used to explore the role of sex, year of data collection, country's economic

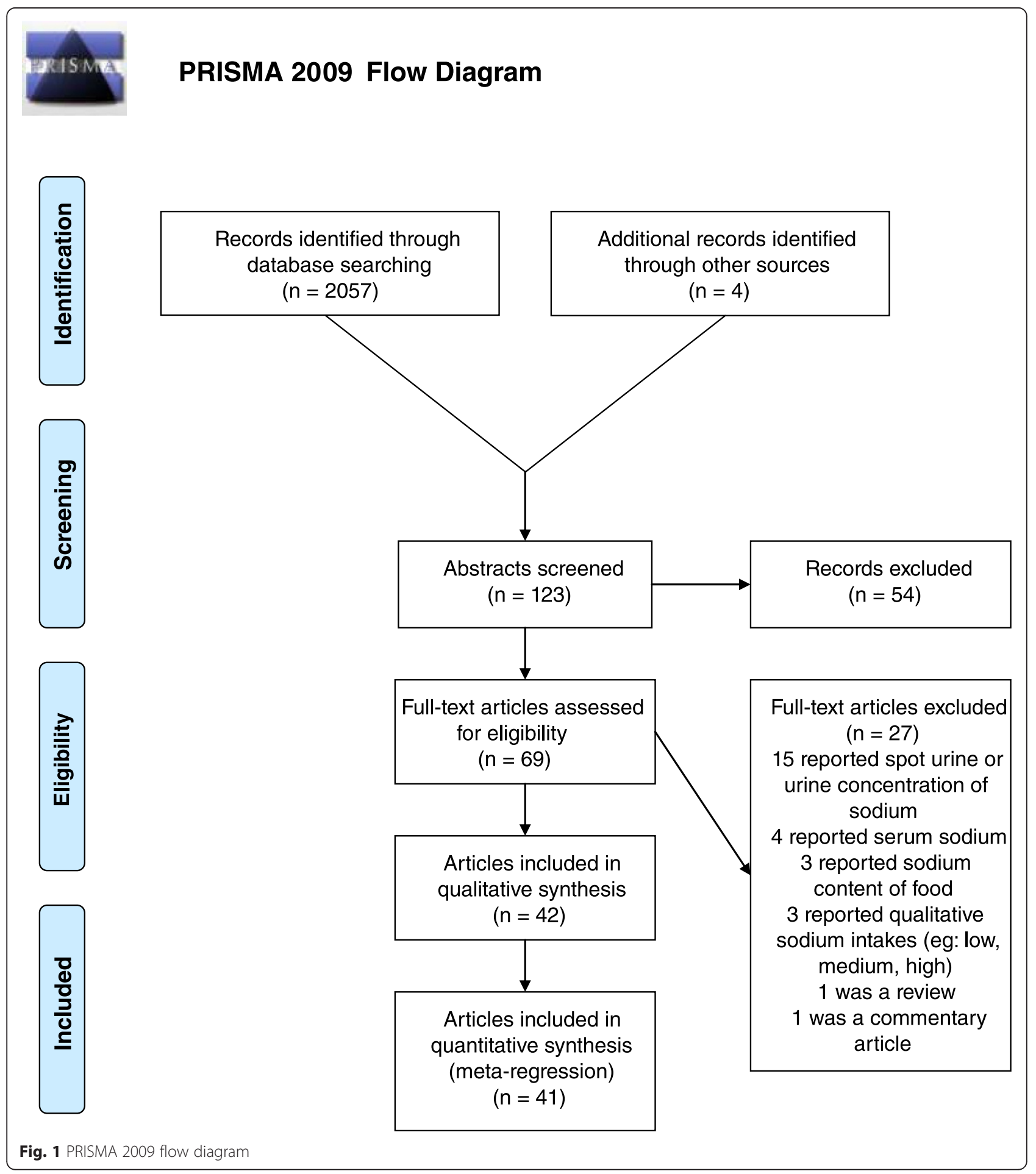


Table 2 Included studies

\begin{tabular}{|c|c|c|c|c|}
\hline Country & Period of data collection & $\begin{array}{l}\text { Population and Quality of } \\
\text { Sample Representativeness }\end{array}$ & $\begin{array}{l}\text { Method and Quality } \\
\text { of Data Collection }\end{array}$ & References \\
\hline Benin & January-February 1996 & $\begin{array}{l}\text { Male school children aged } \\
6-12 \text { and their mothers in } \\
\text { rural Penessoulou, } \\
\text { Atacora. (B). }\end{array}$ & U3 & $\begin{array}{l}\text { Melse-Boonstra et al, } \\
1998 \text { [19] }\end{array}$ \\
\hline Botswana & October 1967, May 1968 & $\begin{array}{l}\text { Male adults recruited } \\
\text { from the Kung bushmen } \\
\text { in Northwestern } \\
\text { Ngamiland. (B). }\end{array}$ & $\cup 4$ & Truswell et al, 1972 [20] \\
\hline Cameroon & 1993-1995 & $\begin{array}{l}\text { Random sample recruited } \\
\text { from the civil service in } \\
\text { Yaounde (affluent urban) } \\
\text { and villages in a district } \\
\text { in the same region } \\
\text { (rural poor). Men and } \\
\text { women aged 25-74. (A). }\end{array}$ & U4 & Cooper et al, 1997 [21] \\
\hline Cote d'Ivoire & Not reported & $\begin{array}{l}\text { Families chosen by the } \\
\text { investigators as } \\
\text { representative of the } \\
\text { populations recruited } \\
\text { from } 3 \text { Northern villages } \\
\text { (Koro, N'deo and Maranama) } \\
\text { and from Abidjan. Children } \\
\text { aged 2-12 and adults. (B). }\end{array}$ & $\begin{array}{l}\text { D4 (all food eaten by } \\
\text { the families for } 3 \\
\text { consecutive days was } \\
\text { weighed by } \\
\text { investigators). U3 } \\
\text { (adults only). }\end{array}$ & Hess et al, 1999 [22] \\
\hline Ghana & February-April 2007 & $\begin{array}{l}\text { Random sample selected } \\
\text { from a population register } \\
\text { recruited from rural } \\
\text { Kassena-Nankana } \\
\text { District. (A). }\end{array}$ & $\begin{array}{l}\text { D4 (household } \\
\text { inventories) }\end{array}$ & $\begin{array}{l}\text { Kunutsor and Powles, } \\
2009 \text { [23] }\end{array}$ \\
\hline Ghana & June 2001-June 2002 & $\begin{array}{l}\text { Random sample selected } \\
\text { from census, recruited from } \\
12 \text { villages, } 6 \text { semi-urban, } \\
6 \text { rural in the Ejisu-Juabeng } \\
\text { and Kumasi Districts. Adults } \\
\text { aged } 40-75,92 \% \text { Ashanti } \\
\text { tribe, } 94 \% \text { Twi-speaking. (A). }\end{array}$ & U4. & $\begin{array}{l}\text { Cappuccio et al, } 2006 \text { [24]; } \\
\text { Kerry et al, } 2005 \text { [25] }\end{array}$ \\
\hline Ghana & June 1997-June 1999 & $\begin{array}{l}\text { Patients aged } 5-12 \text { in the } \\
\text { paediatric surgery unit of } \\
\text { the Korle-Bu Teaching } \\
\text { Hospital, Accra, with } \\
\text { surgical conditions that } \\
\text { did not affect urine volume } \\
\text { (herniae, hydroceles, } \\
\text { undescended testes, } \\
\text { hypospadias and tumours) } \\
\text { and post-operative patients } \\
\text { after surgery for acute } \\
\text { appendicitis who had fully } \\
\text { recovered. All eating a } \\
\text { normal diet. Ready for } \\
\text { discharge but detained for } \\
24 \text { h urine to be collected. (B). }\end{array}$ & U4 & Badoe et al, 2005 [26] \\
\hline Ghana & Not reported & $\begin{array}{l}\text { Patients recruited from Korle-Bu } \\
\text { Teaching Hospital, Accra, } \\
\text { suffering from uncomplicated } \\
\text { hernias, nodular goitre, breast } \\
\text { tumours and simple tumours } \\
\text { eating a full hospital diet. } \\
\text { Adults aged } 20-69 \text {, all } \\
\text { ambulant, no evidence of } \\
\text { urinary disease. (B). }\end{array}$ & U4 & $\begin{array}{l}\text { Badoe and Osafo, } \\
1971[27]\end{array}$ \\
\hline
\end{tabular}


Table 2 Included studies (Continued)

\begin{tabular}{|c|c|c|c|c|}
\hline Kenya & 1986 & $\begin{array}{l}\text { Random sample drawn from } \\
320 \text { households in the rural } \\
\text { villages of Rambugu and } \\
\text { Ndori, north of Lake Victoria } \\
\text { in Western Kenya. Exclusively } \\
\text { from the Luo tribe. Pregnant } \\
\text { women excluded. } \\
\text { (Part of INTERSALT). (A). }\end{array}$ & U3 & Carvalho et al, 1989 [28] \\
\hline Kenya & September 1980-November 1984 & $\begin{array}{l}\text { Recruited from two rural } \\
\text { populations (the Luo tribe } \\
\text { and the Kamba tribe) and } \\
\text { migrants from the Luo } \\
\text { community to Nairobi } \\
\text { (urban migrants). Only spot } \\
\text { urine done on Kamba } \\
\text { population, therefore not } \\
\text { included in this systematic } \\
\text { review. (B). }\end{array}$ & U4 & Poulter et al, 1985 [29] \\
\hline Malawi & Not reported & $\begin{array}{l}\text { All inhabitants from the first } \\
\text { building estate in Lilongwe } \\
\text { (urban, mainly white collar } \\
\text { workers) and from the villages } \\
\text { of Gunde and Msinje (rural, } \\
\text { mainly farmers). Urine requested } \\
\text { from men aged 15+ with } \\
\text { even subject numbers. (B). }\end{array}$ & U4 & Simmons et al, 1986 [30] \\
\hline Nigeria & Not reported & $\begin{array}{l}\text { Recruited from residential } \\
\text { communities in South-western } \\
\text { Nigeria. Excluding pregnant } \\
\text { women and those on } \\
\text { anti-hypertensives. (B). }\end{array}$ & U3 & Tayo et al, 2012 [31] \\
\hline Nigeria & November 2006-January 2007 & $\begin{array}{l}\text { All hypertensive patients } \\
\text { attending the hypertensive } \\
\text { clinic and selected normotensive } \\
\text { controls attending the } \\
\text { outpatient departments of } \\
\text { two specialist hospitals in } \\
\text { Akure and Ondo towns. Adults } \\
\text { aged } 20+\text {. Normotensive } \\
\text { controls only considered in } \\
\text { this review. (B). }\end{array}$ & D3. U5. & $\begin{array}{l}\text { ljarotimi and Keshinro, } \\
2008 \text { [32] }\end{array}$ \\
\hline Nigeria & Not reported & $\begin{array}{l}\text { Recruited from two rural } \\
\text { communities in Southwest } \\
\text { Nigeria Igbo-Ora and Idere. } \\
\text { Excluding pregnant or } \\
\text { breastfeeding women and } \\
\text { people with diabetes, kidney } \\
\text { disease or atherosclerosis and } \\
\text { BMl over 40. Normotensive } \\
\text { men and women. } \\
\text { Aged 25-55. (B). }\end{array}$ & U4 & Forrester, 2005 [33] \\
\hline Nigeria & Not reported & $\begin{array}{l}\text { Free-living adult volunteers } \\
\text { aged 18-48. University staff } \\
\text { and/or their dependents of } \\
\text { lower to high socio-economic } \\
\text { status by Nigerian standards. (B). }\end{array}$ & D1 & Smith, 1988 [34] \\
\hline Nigeria & 1993-1995 & $\begin{array}{l}\text { Random sample recruited } \\
\text { from the rural village of Idere } \\
\text { and } 2 \text { sites within Ibadan: } \\
\text { Idikan traders and crafters } \\
\text { (urban poor) and male } \\
\text { pensioners of the Nigerian } \\
\text { Railway Corporation (urban } \\
\text { salaried). All Oyo Yoruba } \\
\text { aged } 25-74 \text {. (A). }\end{array}$ & U4 & $\begin{array}{l}\text { Kaufman et al, } 1999 \text { [35]; } \\
\text { Cooper et al, } 1997 \text { [21]; } \\
\text { Kaufman et al, } 1996 \text { [36] }\end{array}$ \\
\hline
\end{tabular}


Table 2 Included studies (Continued)

Nigeria Summer 1990

Nigeria

Not reported

South Africa

Not reported

South Africa

$2002-2006$

South Africa

South Africa

March 1981-October 1982

South Africa

Not reported

South Africa

1980
All civil servants in Sokoto, Northern Nigeria excluding pregnant women.

Aged 18-66. (B).

Random sample from two secondary day schools and one primary day school in

Calabar (urban) and one

co-educational secondary

day school and one primary

day school in Akpabuyo

(rural). Boys and girls

aged 12-14. (A)

Random sample selected from housing map, recruited from rural communities of Empangeni, KwaZulu-Natal. Adults 19+ excluding pregnant or breast feeding women. (A).

Random sample selected from recent census, recruited from metropolitan areas of Johannesburg. Adults aged $17+$ of black African descent. (A).

Convenience sample recruited from staff of the Cape Town City Council offices. Including hypertensive and normotensive adults aged 20-65 years old

from three ethnic groups (black, white, mixed). Normotensive population only considered in this review. (B).

Adult patients with hypertension and normotensive controls recruited from two light industrial firms (urban Zulus and urban Indians), from the Lamontville township and the outpatient department of King Edward VIII hospital (urban Zulus), from a satellite clinic of KEVIII hospital (urban Indians) from Bethesda hospital in Ubombo, Benedictine hospital in Nongoma and others from the same communities (rural Zulus). Patients with complications of hypertension or major concomitant illness were excluded from the study. Normotensive controls only considered in this review. (B).

Healthy male volunteers resident in Johannesburg. Aged 20-30 years. (B).

Random sample selected from male employees of a wire-rope manufacturing company near Johannesburg. Aged 30-50 years. (A).
Redelinghuys et al, 2010 [42] 
Table 2 Included studies (Continued)

\begin{tabular}{|c|c|c|c|c|}
\hline South Africa & Not reported & $\begin{array}{l}\text { Normotensive factory workers } \\
\text { and hospital staff and } \\
\text { hypertensive patients. } \\
\text { Normotensive population } \\
\text { only included in this } \\
\text { analysis. (B). }\end{array}$ & U3 & Cohen et al, 1982 [50] \\
\hline South Africa & August-September 1978 & $\begin{array}{l}\text { Urban, apparently healthy, } \\
\text { informed volunteers from } \\
\text { domestic and clinical staff } \\
\text { of the Groote Schuur Hospital, } \\
\text { Cape Town and rural Xhosa } \\
\text { volunteers from villages } \\
\text { surrounding St Lucy's Mission } \\
\text { Hospital in the Transkei. } \\
\text { Excluding those taking any } \\
\text { drug (including oral } \\
\text { contraceptives). (B). }\end{array}$ & $\begin{array}{l}\text { D4 ("a full } \\
\text { dietary history") }\end{array}$ & Sever et al, 1980 [51] \\
\hline Tanzania & Not reported & $\begin{array}{l}\text { 13-21 year old Bantu-speaking } \\
\text { boys/young men from a } \\
\text { secondary boarding school } \\
\text { in Mafinga, Iringa District. (B). }\end{array}$ & $\begin{array}{l}\text { D4 (analysis of } \\
\text { weekly menu) }\end{array}$ & $\begin{array}{l}\text { Rebacz-Maron et al, } \\
2013 \text { [52] }\end{array}$ \\
\hline Tanzania & Not reported & $\begin{array}{l}20-50 \text { year old healthy men } \\
\text { living in Mwanza (urban). (B). }\end{array}$ & U2 & Hamada et al, 2010 [53] \\
\hline Tanzania & 1998 & $\begin{array}{l}\text { Random sampling from } \\
\text { administrative lists recruited } \\
\text { from urban (Dar es Salaam), } \\
\text { rural (Handeni) and } \\
\text { semi-nomadic (Monduli) } \\
\text { communities. Adults aged } \\
\text { 47-57. (A). }\end{array}$ & U2 & Njelekela, 2001 [54] \\
\hline Tanzania & 1987 & $\begin{array}{l}\text { Random sample recruited } \\
\text { from Dar es Salaam (urban), } \\
\text { Handeni (rural) and Moduli } \\
\text { (nomadic-rural). Aged } \\
\text { 30-54. (A). }\end{array}$ & U4 & Mtabaji et al, 1990 [55] \\
\hline Tanzania and Uganda & Not reported & $\begin{array}{l}\text { General population cohorts } \\
\text { from Lugarawa district in } \\
\text { Tanzania and Lugbara in } \\
\text { Uganda. (B). }\end{array}$ & $\begin{array}{l}\text { D4 (detailed } \\
\text { questionnaire } \\
\text { about dietary } \\
\text { habits) }\end{array}$ & Pavan et al, 1997 [56] \\
\hline $\begin{array}{l}\text { The Democratic Republic } \\
\text { of the Congo }\end{array}$ & December 1983-May 1984 & $\begin{array}{l}10 \% \text { random sample of a } \\
\text { quarter of Kinshasa. Aged } \\
10+. \text { Subjects on } \\
\text { anti-hypertensives were } \\
\text { excluded. (A). }\end{array}$ & U2 & $\begin{array}{l}\text { M'Buyamba-Kabangu } \\
\text { et al, } 1986 \text { [57]; } \\
\text { M'Buyamba-Kabangy } \\
\text { et al, } 1986 \text { [58] }\end{array}$ \\
\hline Zimbabwe & Not reported & $\begin{array}{l}\text { Male school children in rural } \\
\text { Zimbabwe. (B). }\end{array}$ & U4 & Matthews and Pegge, 1997 [59] \\
\hline Zimbabwe & Not reported & $\begin{array}{l}\text { Volunteer first year medical } \\
\text { students. Male and female, } \\
\text { average age } 20 \text { years. (B). }\end{array}$ & U2 & Mufunda et al, 1992 [60] \\
\hline
\end{tabular}

development, location (urban or rural), and method of measurement (urinary or dietary) as sources of heterogeneity for the estimated salt intakes of adults. For these analyses we treated semi-urban and seminomadic populations as rural. Country was used to determine the level of economic development of the study setting based on World Bank definitions at the time of writing this paper [17].

Where year of data collection was not recorded, we assumed three years prior to publication, and where a period covering more than one year was recorded, we used the midpoint for the meta-regression analysis.

Where a standard error of the mean was not reported this was calculated using the standard deviation and number of study participants. In some studies either sample number or standard deviation were missing. If sample number was missing but could be approximated from data included in the paper, this was done. In cases where the range was reported, the standard error of the mean was estimated using the range rule [18]. 
Table 3 Sodium intake $(\mathrm{g})$ in adults

\begin{tabular}{|c|c|c|c|c|c|c|c|c|c|c|}
\hline & & Men & & & Women & & & Both & & \\
\hline Study & Population & $n$ & Mean & S.D. & $n$ & Mean & S.D. & $n$ & Mean & S.D. \\
\hline \multicolumn{11}{|l|}{ Benin } \\
\hline Melse-Boonstra et al, 1998 [19] & Rural & - & - & - & 13 & 3.29 & 1.10 & - & - & - \\
\hline \multicolumn{11}{|l|}{ Botswana } \\
\hline Truswell et al, 1972 [20] & Rural (1967) & 6 & 0.71 & $N / S$ & - & - & - & - & - & - \\
\hline Truswell et al, 1972 [20] & Rural (1968) & 4 & 0.67 & $N / S$ & - & - & - & - & - & - \\
\hline \multicolumn{11}{|l|}{ Cameroon } \\
\hline Cooper et al, 1997 [21] & Rural & - & - & - & - & - & - & $N / S$ & 2.03 & 1.10 \\
\hline Cooper et al, 1997 [21] & Urban & - & - & - & - & - & - & N/S & 1.25 & 0.69 \\
\hline \multicolumn{11}{|l|}{ Cote d'Ivoire } \\
\hline Hess et al, 1999 [22] & Rural & - & - & - & - & - & - & 51 & 2.90 & 1.90 \\
\hline Hess et al, 1999 [22] & Urban & - & - & - & - & - & - & 52 & 3.00 & 1.30 \\
\hline \multicolumn{11}{|l|}{ Ghana } \\
\hline Kunutsor and Powles, 2009 [23] & Rural & - & - & - & - & - & - & 78 & 5.20 & N/S \\
\hline Cappuccio et al, 2006 [24]; Kerry et al, 2005 [25] & Rural & - & - & - & - & - & - & 481 & 2.28 & 1.03 \\
\hline Cappuccio et al, 2006 [24]; Kerry et al, 2005 [25] & Semi-Urban & - & - & - & - & - & - & 532 & 2.37 & 1.03 \\
\hline Badoe and Osafo, 1971 [27] & Urban & - & - & - & - & - & - & 131 & 2.62 & $\mathrm{~N} / \mathrm{S}$ \\
\hline \multicolumn{11}{|l|}{ Kenya } \\
\hline Carvalho et al, 1989 [28] & Rural & 90 & 1.39 & 0.84 & 86 & 1.23 & 0.65 & - & - & - \\
\hline Poulter et al, 1985 [29] & Rural Luo & 126 & 0.71 & 0.30 & 78 & 0.80 & 0.53 & - & - & - \\
\hline Poulter et al, 1985 [29] & Migrant Luo & 78 & 1.15 & 0.55 & 61 & 1.08 & 0.51 & - & - & - \\
\hline \multicolumn{11}{|l|}{ Malawi } \\
\hline Simmons et al, 1986 [30] & Urban & - & - & - & - & - & - & 123 & 1.65 & 0.98 \\
\hline Simmons et al, 1986 [30] & Rural & - & - & - & - & - & - & 78 & 0.86 & 0.71 \\
\hline \multicolumn{11}{|l|}{ Nigeria } \\
\hline Tayo et al, 2012 [31] & - & - & - & - & - & - & - & 804 & 2.85 & 1.26 \\
\hline ljarotimi and Keshinro, 2008 [32] & - & 203 & 10.23 & 3.42 & 249 & 10.34 & 2.37 & - & - & - \\
\hline Forrester et al, 2005 [33] & Rural & - & - & - & - & - & - & 58 & 2.14 & 1.21 \\
\hline $\begin{array}{l}\text { Kaufman et al, } 1999 \text { [35]; Cooper et al, } 1997 \text { [21]; } \\
\text { Kaufman et al, } 1996 \text { [36] }\end{array}$ & Rural farmers $(45+)$ & 53 & 2.55 & 1.30 & - & - & - & - & - & - \\
\hline $\begin{array}{l}\text { Kaufman et al, } 1999 \text { [35]; Cooper et al, } 1997 \text { [21]; } \\
\text { Kaufman et al, } 1996 \text { [36] }\end{array}$ & Urban Poor (45+) & 73 & 2.54 & 1.16 & - & - & - & - & - & - \\
\hline $\begin{array}{l}\text { Kaufman et al, } 1999 \text { [35]; Cooper et al, } 1997 \text { [21]; } \\
\text { Kaufman et al, } 1996 \text { [36] }\end{array}$ & Urban Salaried (45+) & 18 & 2.72 & 1.34 & - & - & - & - & - & - \\
\hline $\begin{array}{l}\text { Kaufman et al, } 1999 \text { [35]; Cooper et al, } 1997 \text { [21]; } \\
\text { Kaufman et al, } 1996 \text { [36] }\end{array}$ & Combined (45+) & 144 & 2.57 & 1.23 & 178 & 2.50 & 1.38 & 322 & 2.53 & 1.31 \\
\hline $\begin{array}{l}\text { Kaufman et al, } 1999 \text { [35]; Cooper et al, } 1997 \text { [21]; } \\
\text { Kaufman et al, } 1996 \text { [36] }\end{array}$ & Combined (25-74) & - & - & - & - & - & - & $N / S$ & 2.79 & 1.75 \\
\hline Bunker et al, 1996 [37] & Urban & 378 & 2.63 & 1.82 & 59 & 2.21 & 1.50 & - & - & - \\
\hline Smith, 1988 [34] & Urban & 7 & 4.01 & 0.49 & 9 & 4.30 & 0.89 & 16 & 4.18 & 0.53 \\
\hline \multicolumn{11}{|l|}{ South Africa } \\
\hline Kolahdooz et al, 2013 [39] & Rural & 51 & 2.08 & 1.41 & 84 & 2.20 & 0.80 & - & - & - \\
\hline $\begin{array}{l}\text { Maseko et al, } 2006 \text { [40]; Millen et al, } 2013 \text { [41]; } \\
\text { Redelinghuys et al, 2010 [42] }\end{array}$ & Urban & - & - & - & - & - & - & 635 & 2.42 & 1.68 \\
\hline $\begin{array}{l}\text { Charlton et al, } 2013 \text { [43]; Charlton et al, } 2008 \text { [44]; } \\
\text { Charlton et al, } 2005 \text { [45]; Charlton et al, } 2005 \text { [46] }\end{array}$ & Urban White & - & - & - & - & - & - & 103 & 3.79 & 2.09 \\
\hline
\end{tabular}


Table 3 Sodium intake (g) in adults (Continued)

\begin{tabular}{|c|c|c|c|c|c|c|c|c|c|}
\hline $\begin{array}{l}\text { Charlton et al, } 2013 \text { [43]; Charlton et al, } 2008 \text { [44]; } \\
\text { Charlton et al, } 2005 \text { [45]; Charlton et al, } 2005 \text { [46] }\end{array}$ & Urban Mixed & - & - & - & - & - & - & 112 & 3.39 \\
\hline $\begin{array}{l}\text { Charlton et al, } 2013 \text { [43]; Charlton et al, } 2008 \text { [44]; } \\
\text { Charlton et al, } 2005 \text { [45]; Charlton et al, } 2005 \text { [46] }\end{array}$ & Urban Black & - & - & - & - & - & - & 110 & 3.11 \\
\hline Barlow et al, 1985 [48] & Urban White & 11 & 3.83 & 1.21 & - & - & - & - & - \\
\hline Barlow et al, 1985 [48] & Urban Black & 10 & 3.23 & 0.96 & - & - & - & - & - \\
\hline Hoosen et al, 1985 [47] & Urban Zulus & - & - & - & - & - & - & $N / S$ & 4.41 \\
\hline Hoosen et al, 1985 [47] & Rural Zulus & - & - & - & - & - & - & $N / S$ & 4.19 \\
\hline Hoosen et al, 1985 [47] & Urban Indians & - & - & - & - & - & - & $N / S$ & 2.76 \\
\hline Cohen et al, 1982 [50] & Urban White & - & - & - & - & - & - & 17 & 3.84 \\
\hline Cohen et al, 1982 [50] & Urban Black & - & - & - & - & - & - & 19 & 3.10 \\
\hline Barlow et al, 1982 [49] & Urban White & 34 & 3.83 & 1.44 & - & - & - & - & - \\
\hline Barlow et al, 1982 [49] & Urban Black & 71 & 2.91 & 1.27 & - & - & - & - & - \\
\hline Sever et al, 1980 [51] & Urban & $N / S$ & 5.52 & 1.31 & N/S & 5.52 & 1.72 & 15 & 5.52 \\
\hline Sever et al, 1980 [51] & Rural & $N / S$ & 3.95 & 0.74 & $N / S$ & 3.63 & 1.84 & 15 & 3.72 \\
\hline \multicolumn{10}{|l|}{ Tanzania } \\
\hline Hamada et al, 2010 [53] & Urban & 74 & 2.38 & 1.17 & - & - & - & - & - \\
\hline Njelekela, 2001 [54] & Urban & 81 & 5.20 & 24.80 & 79 & 4.90 & 2.70 & - & - \\
\hline Njelekela, 2001 [54] & Rural & 93 & 3.10 & 1.80 & 91 & 3.00 & 1.80 & - & - \\
\hline Njelekela, 2001 [54] & Semi-Nomadic & 41 & 3.60 & 3.00 & 61 & 3.70 & 2.30 & - & - \\
\hline Mtabaji et al, 1990 [55] & Urban & 103 & 5.60 & 3.40 & 87 & 5.40 & 4.80 & - & - \\
\hline Mtabaji et al, 1990 [55] & Rural & 88 & 4.90 & 2.70 & 96 & 4.20 & 2.40 & - & - \\
\hline Mtabaji et al, 1990 [55] & Semi-Nomadic & 58 & 2.50 & 2.30 & 64 & 2.90 & 2.00 & - & - \\
\hline \multicolumn{10}{|l|}{ Tanzania and Uganda } \\
\hline Pavan et al, 1997 [56] & Rural & & & & & & & 370 & 1.6 \\
\hline \multicolumn{10}{|l|}{ The Democratic Republic of the Congo } \\
\hline $\begin{array}{l}\text { M'Buyamba-Kabangu et al, } 1986 \text { [57]; } \\
\text { M'Buyamba-Kabangy et al, } 1986 \text { [58] }\end{array}$ & Urban & 144 & 2.02 & N/S & 169 & 1.98 & N/S & 313 & 2.00 \\
\hline \multicolumn{10}{|l|}{ Zimbabwe } \\
\hline Mufunda et al, 1992 [60] & Urban & - & - & - & - & - & - & 55 & 4.60 \\
\hline
\end{tabular}

Sensitivity analyses included excluding studies with the lowest quality measurement and excluding non-black populations (populations in sub-Saharan Africa but not of sub-Saharan African descent). The metareg package in Stata 13 was used for all analyses.

\section{Results}

Our search of MEDLINE found 1,057 titles. These were screened and 116 abstracts were retrieved after excluding irrelevant papers. After reading the abstracts, 54 papers were excluded, leaving 62 papers that were retrieved in full. Of these, 37 were found to be relevant. Searching Google Scholar returned 75,700 results. These were ordered by relevance and the first 1,000 titles were reviewed. Three additional papers were retrieved after reviewing these titles. Of these, two were excluded, leaving one paper that included additional reporting of a study previously identified in the MEDLINE search. An additional four papers were found through reference searches. This gave a total of 42 included papers reporting on 34 individual studies [19-60]. Figure 1 is a PRISMA flow chart giving details of the search. Table 2 gives details of included studies.

The 34 studies were carried out in 13 countries and published between 1972 and 2013. Dates of data collection were not reported in all studies, but the earliest reported data collection was in 1967 and the most recent was in 2007. Twenty-seven studies examined adults only, four studies examined children only, and three included both adults and children.

Table 3 and Fig. 2 shows sodium intake in adults reported from 30 studies. By extracting data for male and female, for urban and rural groups, and for black and non-black ethnicity separately (when these were reported), this gave 67 population estimates in total. Thirteen of 67 (19.4\%) populations studied had reported 


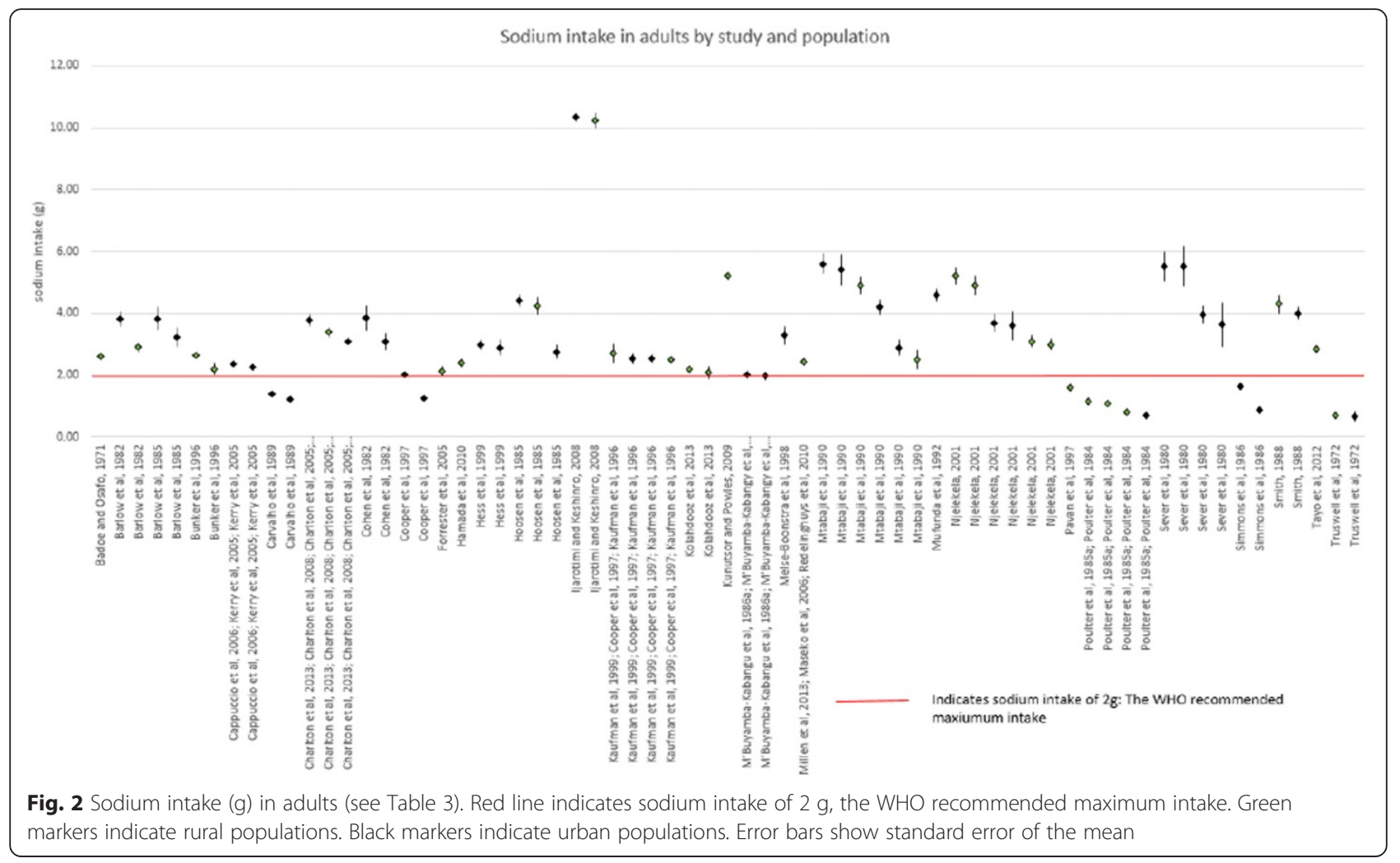

sodium intakes below the WHO recommendation. The two lowest sodium intakes were both found in rural Botswana in the 1960s. Of the others, six were found in Kenya in rural populations and recent migrants, and two from an urban and a rural population from Malawi, studied in the 1980s. The remaining three included one female urban population from the Democratic Republic of the Congo, studied in the 1980s; one urban population from the Cameroon; and one rural population from Tanzania and Uganda, studied in the 1990s.

The highest sodium intake was recorded in a Nigerian population in 2006 at over $10 \mathrm{~g}$ of sodium per day. It is likely, however, that these outliers are unreliable, as $24 \mathrm{~h}$ urine samples were not collected. Instead timed urines were used to calculate possible excretion of a $24 \mathrm{~h}$ time frame. Other high sodium intakes (over $5 \mathrm{~g} /$ day) were reported in populations in Tanzania, South Africa, and Ghana.

In studies that included estimates for both a rural and an urban population, the urban population estimates were higher in almost every case (Cameroonian estimates in Cooper and colleagues, 1997 [21] were one exception). In studies that included estimates for both male and female populations there were ten in which men consumed more salt than women, six in which women consumed more than men, and one in which their consumption was equal.

Two studies (Kunutsor and Powles, 2009 [23]; Pavan and colleagues, 1997 [56]) were excluded from the metaregression as they did not report a standard error of mean or enough data to estimate it. Exploring five potential sources of heterogeneity separately suggested there was an association between year of data collection and salt intake; and between location (urban or rural) and salt intake at the $10 \%$ level, with higher salt intakes in more recent studies and higher salt intakes in urban populations than in rural ones (Table 4).

Multivariate meta-regression showed a significant association between location and salt intake, with

Table 4 Meta-regression entering single covariates

\begin{tabular}{lcll}
\hline Covariate & Coefficient & $\mathrm{Cl}$ & $\mathrm{p}$ \\
\hline Year of data collection & 0.039 & $-0.003-0.081$ & 0.071 \\
Method of data collection (Urinary as reference) & 0.801 & $-0.580-2.181$ & 0.251 \\
Sex (\% men) & -0.103 & $-0.659-0.453$ & 0.713 \\
Economic development (1 = L, 2 = LM, 3 = UM) & 0.212 & $-0.325-0.749$ & 0.433 \\
Location (Rural as reference) & 0.790 & $0.142-1.438$ & 0.018 \\
\hline
\end{tabular}


Table 5 Meta-regression entering all covariates $\beta$ coefficient (95\% confidence interval)

\begin{tabular}{llll}
\hline Covariate & Model 1 & Model 2 (Excluding Q = U5) & Model 3 (Excluding non-black) \\
\hline Year of data collection & $0.012(-0.020-0.044)$ & $0.015(-0.018-0.047)$ & $0.012(-0.023-0.048)$ \\
Method of data collection (Urinary as reference) & $1.136(0.066-2.206)^{*}$ & $1.288(0.211-2.365)^{*}$ & $1.275(0.126-2.422)^{*}$ \\
Sex (\% men) & $-0.061(-0.467-0.345)$ & $-0.044(-0.466-0.379)$ & $-0.064(-0.497-0.368)$ \\
Economic development (1 = L, 2 = LM, 3 = UM) & $-0.034(-0.446-0.378)$ & $-0.159(-0.599-0.281)$ & $-0.124(-0.611-0.362)$ \\
Location (Rural as reference) & $0.874(0.215-1.534)^{*}$ & $1.010(0.326-1.694)^{*}$ & $0.814(0.105-1.523)^{*}$ \\
\hline
\end{tabular}

*significant at $p<0.05$

urban populations consuming higher levels of salt than rural populations; and between measurement used and salt intake, with dietary studies finding higher consumption of salt than urinary studies. These associations were robust in sensitivity analyses (Table 5).

Table 6 shows sodium intake in children. Urban child populations in Ghana, Nigeria, and the Democratic Republic of Congo were consuming more than the adult recommended intake of salt, as was a population of rural children in Benin. The highest recorded sodium intake was in Nigerian girls aged 12-14 who consumed $3.85 \mathrm{~g}$ per day. The lowest sodium intake was found in a male rural population from Zimbabwe who consumed just $0.92 \mathrm{~g}$ per day. In each of the three populations for which girls' and boys' sodium intake was reported separately, girls had a higher sodium intake than boys.

\section{Conclusions}

Through extensive systematic searching focusing on subSaharan Africa and with no date restrictions, we found 42 papers reporting sodium intakes in sub-Saharan African populations, including seven that examined children. The previous systematic reviews in global populations mentioned in the introduction (Brown and colleagues, 2009 [16]; and Powles and colleagues, 2013 [15]) examined papers published between 1988-2008 and 1980-2011, and identified five and 11 papers reporting sodium intakes in sub-Saharan African populations, respectively. Brown and colleagues [16] did not find any estimates for African children, while Powles and colleagues [15] did not include children in their systematic review.
We have found that sodium intake in many adult populations in sub-Saharan Africa is above the $2 \mathrm{~g}$ intake recommended as an upper limit by the WHO, and also above this limit in some populations of children. Indeed, there have been no estimates of sodium intake for adult populations that fell below this $2 \mathrm{~g}$ limit reported since the 1990s. Through meta-regression analyses and by doing a within-study comparison, we have found that sodium intake is likely to be higher in urban than in rural populations. This is an important finding because of the trend for urbanization in sub-Saharan Africa, which will put increasing numbers at risk of hypertension and its sequelae, if this association is robust.

Meta-regression also suggested that dietary methods for assessing sodium intake might give higher estimates of sodium consumption than urinary methods in subSaharan African settings. Estimates of sodium intake based on dietary and urinary methods of estimation each have specific strengths and weaknesses. Although $24 \mathrm{~h}$ urinary excretion is not prone to reporting biases, participant burden is high and this may lead to attrition bias (if quality standards for acceptable collection are stringent) or measurement bias due to incomplete or over-collected urine (where quality standards are lower). In addition, $24 \mathrm{~h}$ urinary excretion takes no account of loss of sodium through other means, for example through feces and/or sweat. Timed urine collection allows for a lesser participant burden, but may be biased because of diurnal variation in sodium excretion [61]. Dietary estimates of sodium intake might not be accurate due to recall bias, reporting errors, erroneous food

Table 6 Sodium intake $(\mathrm{g})$ in children Mean (S.D.) $n$

\begin{tabular}{|c|c|c|c|c|c|c|}
\hline & Urban & & & Rural & & \\
\hline Study & Boys & Girls & Both & Boys & Girls & Both \\
\hline Badoe and colleagues, 2005 [26] & - & - & $2.50(-) 74$ & - & - & - \\
\hline Ekpo and colleagues, 1990 [38] & $1.87(0.94) 20$ & $3.85(1.79) 20$ & - & $1.59(0.75) 19$ & $1.79(0.74) 19$ & - \\
\hline Hess and colleagues, 1999 [22] & - & - & - & - & - & $1.78(0.72) 84$ \\
\hline Matthews and Pegge, 1997 [59] & - & - & - & $0.92(0.65) 32$ & - & - \\
\hline M'Buyuma-Kabangu, 1986 [57] & $1.79(-) 87$ & $2.02(-) 113$ & $1.93(-) 200$ & & & \\
\hline Melse-Boonstra and colleagues, 1998 [19] & - & - & - & $2.71(0.99) 13$ & - & - \\
\hline Rebacz-Maron and colleagues, 2013 [52] & $1.25(-) 91$ & - & - & - & - & - \\
\hline
\end{tabular}


composition tables (for example, because they are not country specific or because they are out-of-date), and/or difficulty in quantifying added salt (including, for example, salt added during cooking but discarded in cooking water, rather than consumed). Our finding that sodium intake estimates are higher based on dietary rather than urinary measures is the opposite of that reported elsewhere [62]. Others have found that estimates based on food diaries, weighed records, food-frequency questionnaires, and $24 \mathrm{~h}$ dietary recall underestimated sodium intakes compared with $24 \mathrm{~h}$ urine collections. It is worth noting though, that despite the meta-regression results, in each of the three included papers that used both dietary and urinary estimates of sodium intake [22, 32, 46], the estimate from dietary data was lower than from urinary data. It is conceivable that in sub-Saharan Africa more sodium is lost through routes other than urinary excretion, for example, through sweat. This is worth considering given that Powles and colleagues [15] found that African sodium intakes (although above WHO recommendations) were lower than the rest of the world, based on $24 \mathrm{~h}$ urinary excretions, uncorrected for non-renal losses.

We did not find a difference between the sexes in sodium intake - in contrast to both global systematic reviews $[15,16]$ that found men consumed more than women, and boys consumed more than girls. In the child populations identified in our review, girls consumed more sodium than boys, though this finding is based on just two studies with fairly small samples sizes. There is no apparent reason why there would be a different association with sex in sub-Saharan Africa than in the rest of the world. However, the fact that there may be a difference suggests that context-specific research needs to be done to establish whether patterns of sodium intake in sub-Saharan African settings are similar to or different from high-income countries or other LMICs.

In this study we have not examined potassium intake, which may mitigate the effects of high sodium on blood pressure. Understanding sodium intake in sub-Saharan Africa in the context of the whole diet could give additional levers with which to tackle cardiovascular disease risk.

Of 66 estimates of sodium intake for adults identified in this review, only 20 were given a measurement quality score of 1 or 2 , and just 28 were rated grade A for sampling strategy. This demonstrates that high quality studies of sodium intake in Africa remain rare. It also means that the implications of our results are limited - it is possible that sodium intake in sub-Saharan African countries differs to the estimates reported here. High quality measurements in representative samples of the general population will be required to identify where and with whom to intervene in order to meet the WHO target of a $30 \%$ reduction in population sodium intake and to demonstrate progress towards this target.

\section{Abbreviations}

CVD: cardiovascular disease; LMICs: low- and middle-income countries; NCD: non-communicable disease; WHO: World Health Organization.

\section{Competing interests}

The authors declare that they have no competing interests.

\section{Authors' contributions}

OO performed the searches, extracted data, performed the meta-regression, and wrote the first draft of the manuscript. SO extracted data. Y-FC helped design the quality assurance and meta-regression analyses. All authors contributed to conception and drafting the manuscript, and all read and approved the final manuscript.

\section{Acknowledgments}

The authors would like to thank Peter Chilton (University of Warwick) for checking and preparing the manuscript, and the University of Warwick Library staff for retrieval of articles for this review. This work was supported by the National Institute for Health Research (NIHR) Collaboration for Leadership in Applied Health Research and Care (CLAHRC) West Midlands. Views expressed are those of the authors and not necessarily those of any funding body or the NHS. The funders had no role in any aspect of the manuscript.

\section{Author details}

${ }^{1}$ Warwick Medical School, University of Warwick, Gibbet Hill Campus, Coventry CV4 7AL, UK. ${ }^{2}$ African Population and Health Research Centre, Manga Close, Off Kirawa Road, P.O. Box 10787-00100, Nairobi, Kenya. ${ }^{3}$ Department of Global Health, Academic Medical Center, University of Amsterdam, and Amsterdam Institute for Global Health and Development, PO Box 227001100 DE Amsterdam, The Netherlands.

Received: 3 July 2015 Accepted: 8 December 2015

Published online: 11 January 2016

References

1. Lozano R, Naghavi M, Foreman K, Lim S, Shibuya K, Aboyans V, et al. Global and regional mortality from 235 causes of death for 20 age groups in 1990 and 2010: a systematic analysis for the Global Burden of Disease Study 2010. Lancet. 2012;380(9859):2095-128.

2. Murray CJL, Vos T, Lozano R, Naghavi M, Flaxman AD, Michaud C, et al. Disability-adjusted life years (DALYS) for 291 diseases and injuries in 21 regions, 1990-2010: a systematic analysis for the Global Burden of Disease Study 2010. Lancet. 2012;380(9859):197-2223.

3. World Health Organization. Global status report on noncommunicable diseases 2010. Geneva: World Health Organization; 2011.

4. Owolabi MO, Mensah GA, Kimmel PL, Adu D, Ramsay M, Waddy SP, et al. Understanding the rise in cardiovascular diseases in Africa: harmonising H3Africa genomic epidemiological teams and tools. Cardiovasc J Afr. 2014;25(3):134-6.

5. Strong K, Mathers C, Bonita R. Preventing stroke: saving lives around the world. Lancet Neurol. 2007;6(2):182-7.

6. Mozaffarian D, Fahimi S, Singh GM, Micha R, Khatibzadeh S, Engell RE, et al. Global sodium consumption and death from cardiovascular causes. New Engl J Med. 2014;371(7):624-34.

7. Aburto NJ, Ziolkovska A, Hooper L, Elliott P, Cappuccio FP, Meerpohl JJ. Effect of lower sodium intake on health: systematic review and meta-analyses. BMJ. 2013;346:f1326.

8. Wang XQQ, Terry PDD, Yan H. Review of salt consumption and stomach cancer risk: epidemiological and biological evidence. World J Gastroenterol. 2009:15(18):2204-13

9. Forrester T. Historic and early life origins of hypertension in Africans. J Nutr. 2004;134(1):211-6.

10. Young JH, Chang YPP, Kim JDOD, Chretien JPP, Klag MJ, Levine MA, et al. Differential susceptibility to hypertension is due to selection during the out-of-Africa expansion. PLoS Genet. 2005;1(6):e82.

11. Campbell NR, Correa-Rotter R, Cappuccio FP, Webster J, Lackland DT, Neal B, et al. Proposed Nomenclature for Salt Intake and for Reductions in Dietary Salt. J Clin Hypertens. 2015;17(4):247-51. 
12. World Health Organization: WHO Guideline: Sodium intake for adults and children. http://apps.who.int/iris/bitstream/10665/77985/1/9789241504836 eng.pdf?ua=1\&ua=1 (2012). Accessed 11th Jan 2016.

13. Sixty-Sixth World Health Assembly: Follow-up to the Political Declaration of the High-level Meeting of the General Assembly on the Prevention and Control of Non-Communicable Diseases. http://apps.who.int/gb/ebwha/ pdf_files/WHA66/A66_R10-en.pdf (2013). Accessed 11th Jan 2016.

14. McLean RM. Measuring population sodium intake: a review of methods. Nutrients. 2014;6(11):4651-62.

15. Powles J, Fahimi S, Micha R, Khatibzadeh S, Shi P, Ezzati M, et al. Global, regional and national sodium intakes in 1990 and 2010: a systematic analysis of $24 \mathrm{~h}$ urinary sodium excretion and dietary surveys worldwide. BMJ Open. 2013:3(12):e003733.

16. Brown IJ, Tzoulaki I, Candeias V, Elliott P. Salt intakes around the world: implications for public health. Int J Epidemiol. 2009:38(3):791-813.

17. The World Bank: Country and Lending Groups. http://data.worldbank. org/about/country-and-lending-groups\#Sub_Saharan_Africa (2015). Accessed 11th Jan 2016.

18. Hozo SPP, Djulbegovic B, Hozo I. Estimating the mean and variance from the median, range, and the size of a sample. BMC Med Res Methodol. 2005:5(1):13.

19. Melse-Boonstra A, Rozendaal M, Rexwinkel H, Gerichhausen MJ, van den Briel T, Bulux J, et al. Determination of discretionary salt intake in rura Guatemala and Benin to determine the iodine fortification of salt required to control iodine deficiency disorders: studies using lithium-labeled salt. Am J Clin Nutr. 1998;68(3):636-41.

20. Truswell AS, Kennelly BM, Hansen JD, Lee RB. Blood pressures of Kung bushmen in Northern Botswana. Am Heart J. 1972;84(1):5-12.

21. Cooper R, Rotimi C, Ataman S, McGee D, Osotimehin B, Kadiri S, et al. The prevalence of hypertension in seven populations of west African origin. Am J Public Health. 1997;87(2):160-8.

22. Hess SY, Zimmermann MB, Staubli-Asobayire F, Tebi A, Hurrell RF. An evaluation of salt intake and iodine nutrition in a rural and urban area of the Côte d'Ivoire. Eur J Clin Nutri. 1999:53(9):680-6.

23. Kunutsor S, Powles J. Descriptive epidemiology of blood pressure in a rural adult population in Northern Ghana. Rural Remote Health. 2009;9(2):1095.

24. Cappuccio FP, Kerry SM, Micah FB, Plange-Rhule J, Eastwood JB. A community programme to reduce salt intake and blood pressure in Ghana. BMC Public Health. 2006;6:13.

25. Kerry SM, Emmett L, Micah FB, Martin-Peprah R, Antwi S, Phillips RO, et al. For the patient. How much salt is used in Ashanti, West Africa? Ethn Dis. 2005:15(1):150-1.

26. Badoe EO, Appeadu-Mensah W, Hesse A, Maddy SO. The daily water sodium and potassium excretion in urine of Ghanaian children aged 5 to 12 years. West Afr J Med. 2005;24(3):231-3.

27. Badoe EA, Osafo TD. The daily urinary volume, sodium and potassium in adult Ghanaians. West Afr Med J Niger Pract. 1971;20(6):352-3.

28. Carvalho JJ, Baruzzi RG, Howard PF, Poulter N, Alpers MP, Franco LJ, et al. Blood pressure in four remote populations in the INTERSALT Study. Hypertension. 1989;14(3):238-46.

29. Poulter NR, Khaw KT, Mugambi M, Peart WS, Sever PS. Migration-induced changes in blood pressure: a controlled longitudinal study. Clin Exp Pharmacol Physiol. 1985;12(3):211-6.

30. Simmons D, Barbour G, Congleton J, Levy J, Meacher P, Saul H, et al. Blood pressure and salt intake in Malawi: an urban rural study. J Epidemiol Community Health. 1986;40(2):188-92.

31. Tayo BO, Luke A, McKenzie CA, Kramer H, Cao G, Durazo-Arvizu R, et al. Patterns of sodium and potassium excretion and blood pressure in the African Diaspora. J Hum Hypertens. 2012;26(5):315-24.

32. Jjarotimi OS, Keshinro OO. Nutritional knowledge, nutrients intake and nutritional status of hypertensive patients in Ondo State, Nigeria. Tanzan J Health Res. 2008;10(2):59-67.

33. Forrester T, Adeyemo A, Soarres-Wynter S, Sargent L, Bennett F, Wilks R, et al. A randomized trial on sodium reduction in two developing countries. J Hum Hypertens. 2005;19(1):55-60.

34. Smith IF. Sodium and potassium intakes amongst free-living adult Nigerians. Eur J Clin Nutr. 1988;42(6):531-7.

35. Kaufman JS, Owoaje EE, Rotimi CN, Cooper RS. Blood pressure change in Africa: case study from Nigeria. Hum Biol. 1999;71(4):641-57.

36. Kaufman JS, Owoaje EE, James SA, Rotimi CN, Cooper RS. Determinants of hypertension in West Africa: contribution of anthropometric and dietary factors to urban-rural and socioeconomic gradients. Am J Epidemiol. 1996:143(12):1203-18.

37. Bunker CH, Okoro Fl, Markovic N, Thai N, Pippin B, Ackrell M, et al. Relationship of hypertension to socioeconomic status in a west African population. Ethn Health. 1996;1(1):33-45.

38. Ekpo EB, Udofia $\mathrm{O}$, Andy JJ. A disappearing urban/rural blood pressure difference in Nigerian children: an evaluation of possible determining factors. Ann Trop Paediatr. 1990;10(2):211-9.

39. Kolahdooz F, Spearing K, Sharma S. Dietary adequacies among South African adults in rural KwaZulu-Natal. PLoS One. 2013;8(6):e67184.

40. Maseko MJ, Majane HO, Milne J, Norton GR, Woodiwiss AJ. Salt intake in an urban, developing South African community. Cardiovasc J S Afr. 2006:17(4):186-91.

41. Millen AM, Norton GR, Majane OH, Maseko MJ, Brooksbank R, Michel FS, et al. Insulin resistance and the relationship between urinary $\mathrm{Na}(+) / \mathrm{K}(+)$ and ambulatory blood pressure in a community of African ancestry. Am J Hypertens. 2013:26(5):708-16.

42. Redelinghuys M, Norton GR, Scott L, Maseko MJ, Brooksbank R, Majane OH, et al. Relationship between urinary salt excretion and pulse pressure and central aortic hemodynamics independent of steady state pressure in the general population. Hypertension. 2010;56(4):584-90.

43. Charlton KE, Jooste PL, Steyn K, Levitt NS, Ghosh A. A lowered salt intake does not compromise iodine status in Cape Town, South Africa, where salt iodization is mandatory. Nutrition. 2013;29(4):630-4.

44. Charlton KE, Steyn K, Levitt NS, Jonathan D, Zulu JV, Nel JH. Development and validation of a short questionnaire to assess sodium intake. Public Health Nutr. 2008;11(1):83-94.

45. Charlton KE, Steyn K, Levitt NS, Zulu JV, Jonathan D, Veldman FJ, et al. Ethnic differences in intake and excretion of sodium, potassium, calcium and magnesium in South Africans. Eur J Cardiovasc Prev Rehabil. 2005;12(4):355-62.

46. Charlton KE, Steyn K, Levitt NS, Zulu JV, Jonathan D, Veldman FJ, et al. Diet and blood pressure in South Africa: Intake of foods containing sodium, potassium, calcium, and magnesium in three ethnic groups. Nutrition. 2005;21(1):39-50.

47. Hoosen S, Seedat YK, Bhigjee Al, Neerahoo RM. A study of urinary sodium and potassium excretion rates among urban and rural Zulus and Indians. J Hypertens. 1985:3(4):351-8.

48. Barlow RJ, Connell MA, Milne FJ. A study of 48-hour faecal and urinary electrolyte excretion in normotensive black and white South African males. J Hypertens. 1986;4(2):197-200.

49. Barlow RJ, Connell MA, Levendig BJ, Gear JS, Milne FJ. A comparative study of urinary sodium and potassium excretion in normotensive urban black and white South African males. S Afr Med J. 1982;62(25):939-41.

50. Cohen SL, Jhetam D, Da Silva J, Milne FJ, van der Walt A. Sodium and potassium status, plasma renin and aldosterone profiles in normotensive and hypertensive Johannesburg blacks. S Afr Med J. 1982:62(25):941-4.

51. Sever PS, Gordon D, Peart WS, Beighton P. Blood-pressure and its correlates in urban and tribal Africa. Lancet. 1980:2(8185):60-4

52. Rębacz-Maron E, Baranowska-Bosiacka I, Gutowska I, Chlubek D. Blood pressure and levels of $\mathrm{Fe}, \mathrm{Ca}, \mathrm{Mg}, \mathrm{Zn}, \mathrm{Cu}, \mathrm{Na}$ and $\mathrm{K}$ in the hair of young Bantu men from Tanzania. Biol Trace Elem Res. 2013:151(3):350-9.

53. Hamada A, Mori M, Mori H, Muhihi A, Njelekela M, Masesa Z, et al. Deterioration of traditional dietary custom increases the risk of lifestyle-related diseases in young male Africans. J Biomed Sci. 2010;17 Suppl 1:S34.

54. Njelekela $M$, Negishi $H$, Nara $Y$, Tomohiro M, Kuga S, Noguchi $T$, et al. Cardiovascular risk factors in Tanzania: a revisit. Acta Trop. 2001;79(3):231-9.

55. Mtabaji JP, Nara Y, Moriguchi Y, Yamori Y. Diet and hypertension in Tanzania. J Cardiovasc Pharmacol. 1990;16 Suppl 8:S3-5.

56. Pavan L, Casiglia E, Pauletto P, Batista SL, Ginocchio G, Kwankam MM, et al. Blood pressure, serum cholesterol and nutritional state in Tanzania and in the Amazon: comparison with an Italian population. J Hypertens. 1997:15(10):1083-90.

57. M'Buyamba-Kabangu JR, Fagard R, Lijnen P, Mbuy wa Mbuy R, Staessen J, Amery A. Blood pressure and urinary cations in urban Bantu of Zaire. Am J Epidemiol. 1986;124(6):957-68.

58. M'Buyamba-Kabangu JR, Lijnen P, Staessen J, Fagard R, Lissens W, Mbuy wa Mbuy $R$, et al. Relationships between blood pressure and urinary sodium, potassium, calcium and magnesium in Bantu of Zaire. J Hypertens Suppl. 1986;4(6):S27-30. 
59. Matthews J, Pegge N. Asthma and consumption of salt. Lancet. 1997;350(9082):957.

60. Mufunda J, Chimoskey JE, Matenga J, Musabayane C, Sparks HV. Blood pressure response to acute changes in dietary sodium in young Zimbabwean men. J Hypertens. 1992;10(3):279-85.

61. Wesson LG. Electrolyte Excretion in Relation to Diurnal Cycles of Renal Function. Medicine. 1964;43:547-92.

62. World Health Organization: Sodium intakes around the world. Background document prepared for the Forum and Technical meeting on reducing salt intake in populations (Paris 5-7 ${ }^{\text {th }}$ October 2006). http://www.who.int/ dietphysicalactivity/Elliot-brown-2007.pdf (2006). Accessed 11th Jan 2016.

Submit your next manuscript to BioMed Central and we will help you at every step:

- We accept pre-submission inquiries

- Our selector tool helps you to find the most relevant journal

- We provide round the clock customer support

- Convenient online submission

- Thorough peer review

- Inclusion in PubMed and all major indexing services

- Maximum visibility for your research

Submit your manuscript at www.biomedcentral.com/submit
Biomed Central 